\title{
ECO-DESIGN. FURNITURE MADE OF RECYCLING MATERIALS - A NEW CONCEPT FOR THE CONTEMPORAN DESIGN
}

\author{
Angela Munteanu*, ORCID ID: 0000-0003-4671-022X \\ Technical University of Moldova, 168 Ștefan cel Mare și Sfânt Blvd., Chișinău, Republic of Moldova \\ *Corresponding author: Angela Munteanu, angela.munteanu@arh.utm.md
}

Received: 07. 14. 2021

Accepted: 08. 22. 2021

\begin{abstract}
The concept of ecodesign appeared in the late XX century, as a trend to return to the organic origins of architecture and design. The ecological house is a modern and economical housing solution that combines recycled, biodegradable and non-polluting materials with new systems and technologies to reduce the costs of heating, air conditioning and lighting. Eco-design is a whole philosophy against the depletion of natural resources and in support of ecological cleanliness and safety. The article tries to convey the message of the ecological problem in the process of training future architects and designers by applying sustainable thinking and design in professional activity, starting from the green stereotype to a practical application through technology.
\end{abstract}

Keywords: eco-design, recycle, pollution, architecture, sustainable.

Rezumat. Conceptul de proiectare ecologică a apărut la sfârșitul secolului XX, ca o tendință de a reveni la originile organice ale arhitecturii și designului. Casa ecologică este o soluție modernă și economică de locuințe care combină materiale reciclate, biodegradabile și nepoluante cu sisteme și tehnologii noi pentru a reduce costurile de încălzire, aer condiționat și iluminat. Eco-designul este o întreagă filozofie împotriva epuizării resurse și în sprijinul curățeniei și siguranței ecologice. Articolul încearcă sa transmită mesajul problemei ecologice in procesul de instruire a viitorilor arhitecți și designeri prin aplicarea gândirii și proiectării durabile în activitatea profesională, începând de la stereotipul verde către o aplicație practică prin tehnologie.

Cuvinte-cheie: proiectare ecologică, reciclare, poluare, arhitectură, durabilă.

\section{Introduction}

We all know that natural resources are limited, and their irrational use has caused an imbalance in nature. Eco-design tries to reduce the effects on the environment from the first phase of product design. The main aspects of eco-design are considering the extension of product life, better use of materials, reducing waste emissions

Eco-design helps to connect shared efforts in green architecture, sustainable agriculture, ecological engineering, ecological restoration and other fields. Eco-design is a discipline that complements interior design. 
The term eco-design was first used in 1998 by John Button, an Australian politician, Ecology Minister, arguing for eco-friendly interior design. Victor Papanek (1923-1998), a design philosopher and a tireless promoter, eloquent of design purposes and approaches that would be sensitive to social and environmental considerations offered a perspective on sustainable impact. He wrote that "design has become the most powerful tool with which human shapes his tools and environments (and, by extension, society and himself)," material published in his 1972 paper, "Design for the Real World. "Design for the Real World: Human Ecological and Social Change", themes of greater relevance to today's design than ever before $[3,4]$.

„Nature does not ask us to be brilliant, it is enough to be rational"

M. Fulger/

\section{Human impact on the environment}

It is well known that humanity consumes more natural resources than the planet can provide, and the rate of consumption is a threat to the future prosperity of mankind.

Humans destroy the planet, they started polluting the Earth 11,000 years ago, from the beginning of civilization:

- since then, and until now, about 13 trillion trees have been cut down;

- about 1,000 children die every day in India due to diseases caused by polluted water;

- about 15 million children die globally due to water pollution;

- a study by the Health Effects Institute (HEI) shows that only 5\% of the world's population still breathes fresh air;

- 8.8 million people die annually in the world due to air pollution, according to a study published in the European Heart Journal [4 - 7].

Thus, some predictions have been made about what awaits us in 2050

- by 2050, 5 billion people out of the total of 9.7 billion projected for that date will live in areas with serious risks to water resources;

- Lack of proper and balanced nutrition will especially affect children, and malnutrition will be a problem for about 7.5 million children worldwide, moderately or severely, says WHO.

- At this rate, between one-third and nearly half of tropical forests will disappear by 2050 , say climatologists [5 - 8].

Today, in the 21st century, the age of developed technologies conditions the environmental impact factors: gas emissions, resource depletion, waste pollution, therefore more and more attention is paid to the global problem - the ecological problem. It is imperative to look for new construction solutions that are environmentally friendly to reduce the consumption of materials and energy.

The issue of sustainable design is a hotly debated issue today, so architecture and design are areas that need to help stop environmental pollution and create new opportunities by eliminating harmful materials, which cost a lot of resources, and various processes that removes harmful substances.

\section{Eco-design}

"In nature nothing is lost, nothing is gained, everything is transformed" /Antoine Lavoisier/

Ecological design consists in integrating environmental protection criteria on a life cycle of a product. The main purpose of eco-design is to reduce the negative impact on the environment (manufacturing, use and disposal of products). Eco-design is part of a global 
approach called "multi-step and" multi-criteria. This approach supports the entire life cycle of a product in a circular economy perspective by saving and recycling at maximum natural resources.

The use of environmentally efficient resources is an important aspect, but the concept of ecological design goes beyond this, taking into account the environmental, social and economic benefits, as well as an attractive, aesthetic and sustainable design. Eco-design is an evolving concept of the future, which is considered an affordable solution to reduce the negative impact of materials on the environment, using recyclable materials, so we get a chance to promote eco-innovation $[1,7]$.

\section{Eco-design principles}

- ease of use and recycling through a successful design;

- use of fewer materials and resources for production;

- use of materials and resources obtained with minimal impact on the environment;

- production of as little waste and pollution as possible;

- reducing the ecological impact of distribution;

To recycle means to consume efficiently, to reuse, to transform, so that there is a permanent circuit of matter that can always be reused and that produces beneficial effects for both people and the environment.

Benefits of recycling: reduction of the amount of energy and raw materials needed to manufacture new products; returns to the economic circuit important quantities of raw material; reduces the quantities stored in garbage dumps or incinerators; reduces the risks to our health and the environment caused by improper discharge of hazardous waste; reduces water and air pollution.

Eco-friendly materials are a challenge for designers, architects, technologists as well as for the users. The choice of materials used in eco-design will also take into account the possible technologies to be used for their processing. Environmentally sound technologies protect the environment, are less polluting, use resources sustainably, recycle a greater proportion of the waste they generate and transport waste in a more environmentally acceptable way compared to the technologies they replace $[1,7,8]$.

"Those who have the privilege of knowing have the duty to act"

/Albert Einsten/

A possible design strategy for recycling is to design recyclable products and use recycled materials (often in the form of waste) to replace virgin materials, in accordance with the principles of the circular economy.

Ecology in this context means the set of actions aimed at minimizing the consumption of energy and natural resources, as well as the production of waste and emissions. An organic product is a product made, used, recycled and stored in a natural way.

The problems of sustainable development nowadays belong to architects and designers. They are in the key position to influence the ecological production and exploitation of the most diverse objects.

Eco design reflects human's desire to bring his home as close as possible to natural conditions.

The creation of the ecological interior allows the inhabitants to feel the unity with nature, the harmony of the surrounding world, to take a break from the hustle and bustle of urban life [8 - 12]. 


\section{Eco projects from recycled materials, made by future architects}

"As a great artist, nature knows how to achieve great effects with small means"

/Heinrich Heine/

Solutions for ecological design, a synthesis activity between art, design and engineering are the pieces of eco furniture, which were executed and presented by the student-architects of the 5th year (October 30, 2019), within the Scientific-Practical Seminar, with the theme: "Eco-design. Sustainable furniture pieces", Faculty of Urbanism and Architecture, department and study program Architecture Figure 1.

The concept of idea, the creation of the model, the use of recycled materials, was the task of the Project of the Year, within the course unit "Interior Architecture" for students of academic groups ARH-151, 152, 153; ARH-141, 142, challenged to develop sustainable "green" furniture and lighting fixtures, respecting functionality, aesthetics and durability.

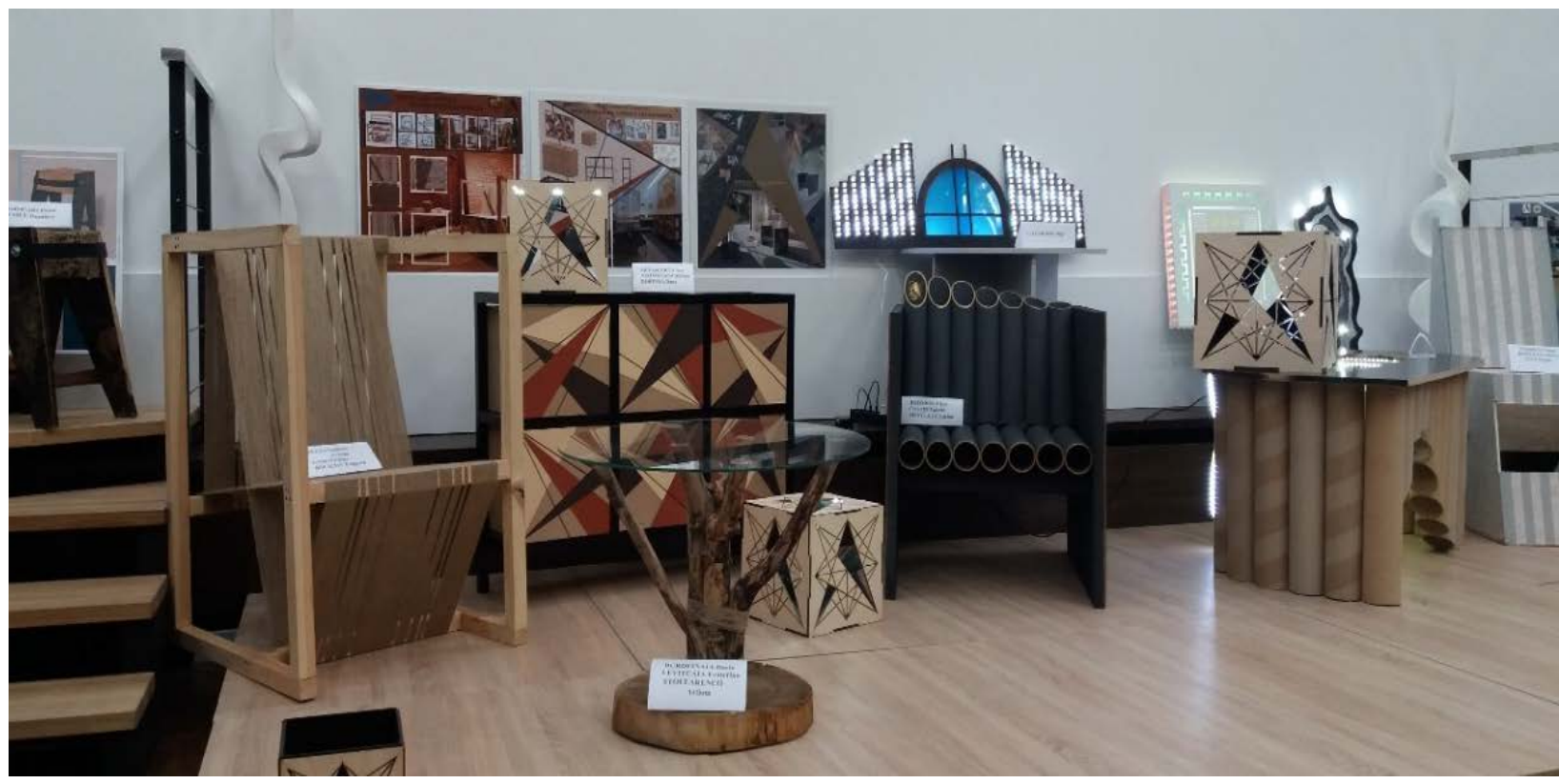

Figure 1. Exhibition of eco-projects from the Scientific-Practical Seminar:

Eco-design. Sustainable furniture.

Inspired by the sustainability movement that is gaining ground in various industries, future architects have accepted the challenge of using recycled materials: pressed cardboard, embossed, cardboard tubes, colored magazines, wood: old furniture, construction wood, metal, tires etc., managing to make unique furniture objects, pleasing to the eye and heart.

Involved in the given eco-project, the students grouped in work teams, followed several stages: analysis of the eco problem, bionic form found in nature; researching the problem, determining the $100 \%$ recycled materials, the type of furniture; concept creation elaboration of sketches, digital modeling of the model, assembly of the conceived piece.

"Armchair of the Architecture Department" is the work of the team Boțoroga lon, Costin Valeria, Musteața Adrian (gr. ARH 152), who used cardboard cylinders, and $100 \%$ recyclable OSB boards. On the sides, the logo of the Architecture department was attached, making the connection between the furniture object and the specialty they graduate, being the most important element of the piece of furniture. "Figure 2". This "green" piece of furniture - a symbol of the department will be kept in the faculty museum, as an example to follow. 

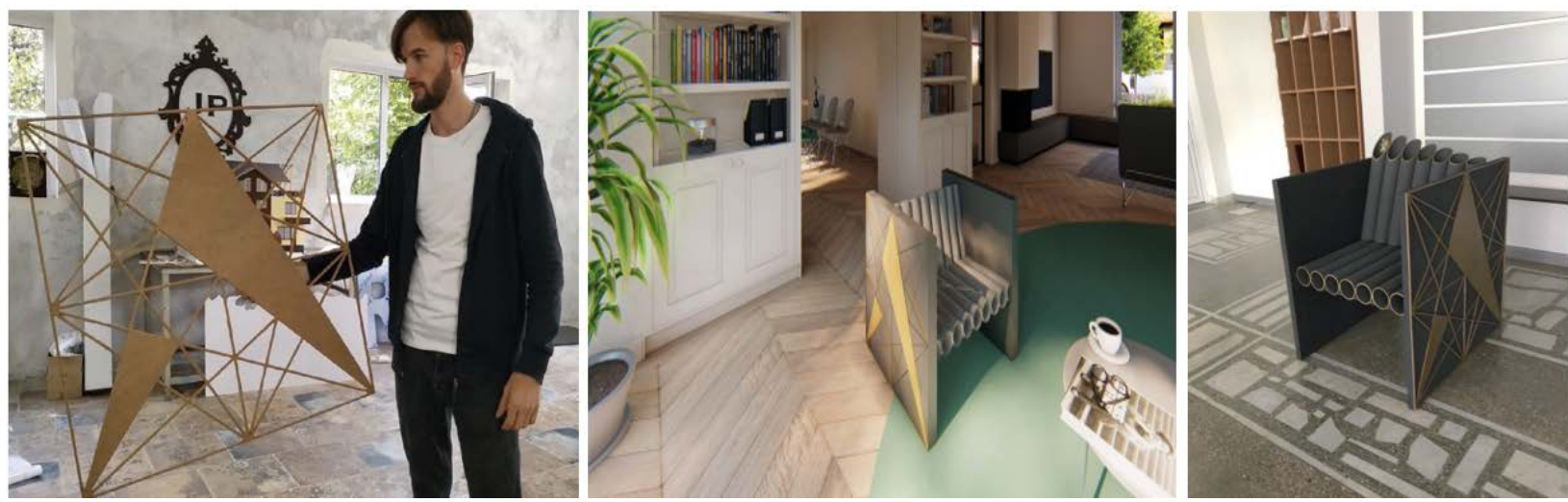

Figure 2. The work "Armchair of the Architecture Department" authors:

Boțoroga Ion, Costin Valeria, Musteața Adrian, gr. ARH 152.

"Loom chair", is the work of the team Alexandrov Artem, Lașun Elena, Bocicov Evghenii (gr. ARH-153) from reused wood from construction and hemp ropesThe special shape and comfort of the furniture object found inspiration from the loom in the house of the Romanian peasants Figure 2, 3, 4.

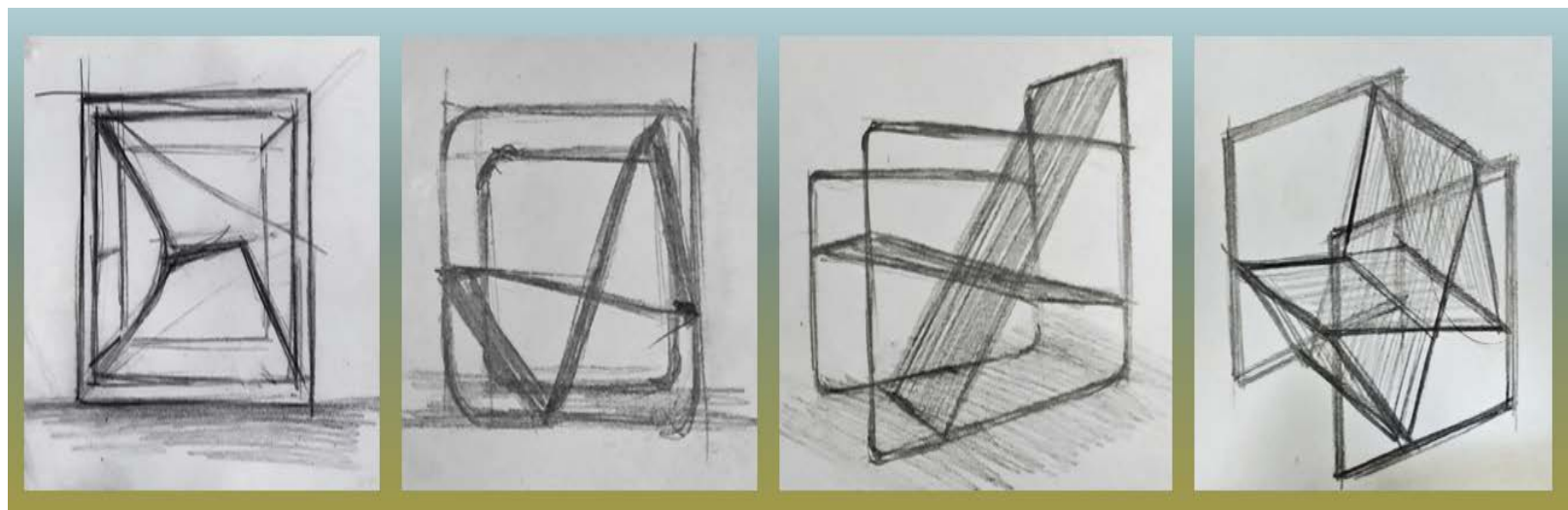

Figure 3. Sketches for the project "Loom chair", authors: Alexandrov Artem, Lașun Elena, Bocicov Evghenii, gr. ARH-153.

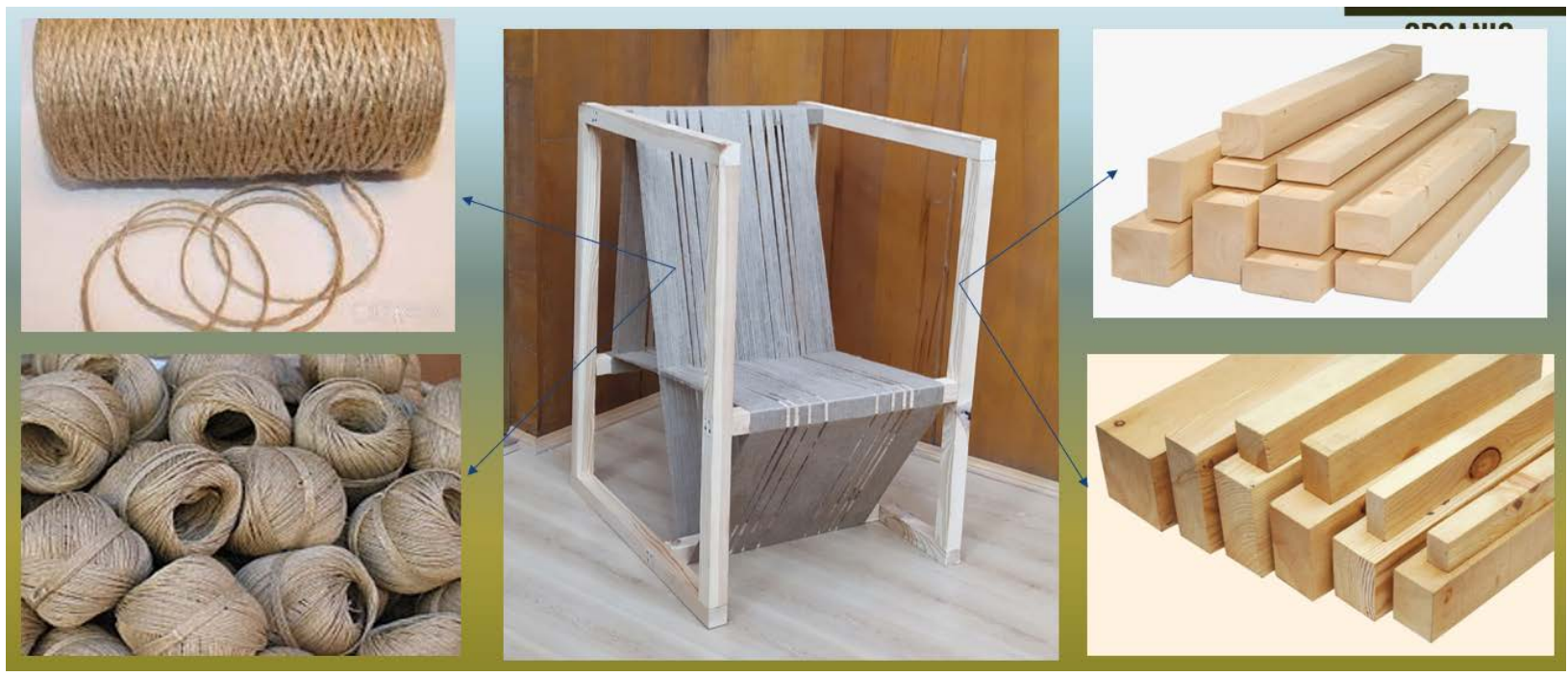

Figure 4. "Loom chair", authors: Alexandrov Artem, Lașun Elena, Bocicov Evghenii, gr. ARH-153. 


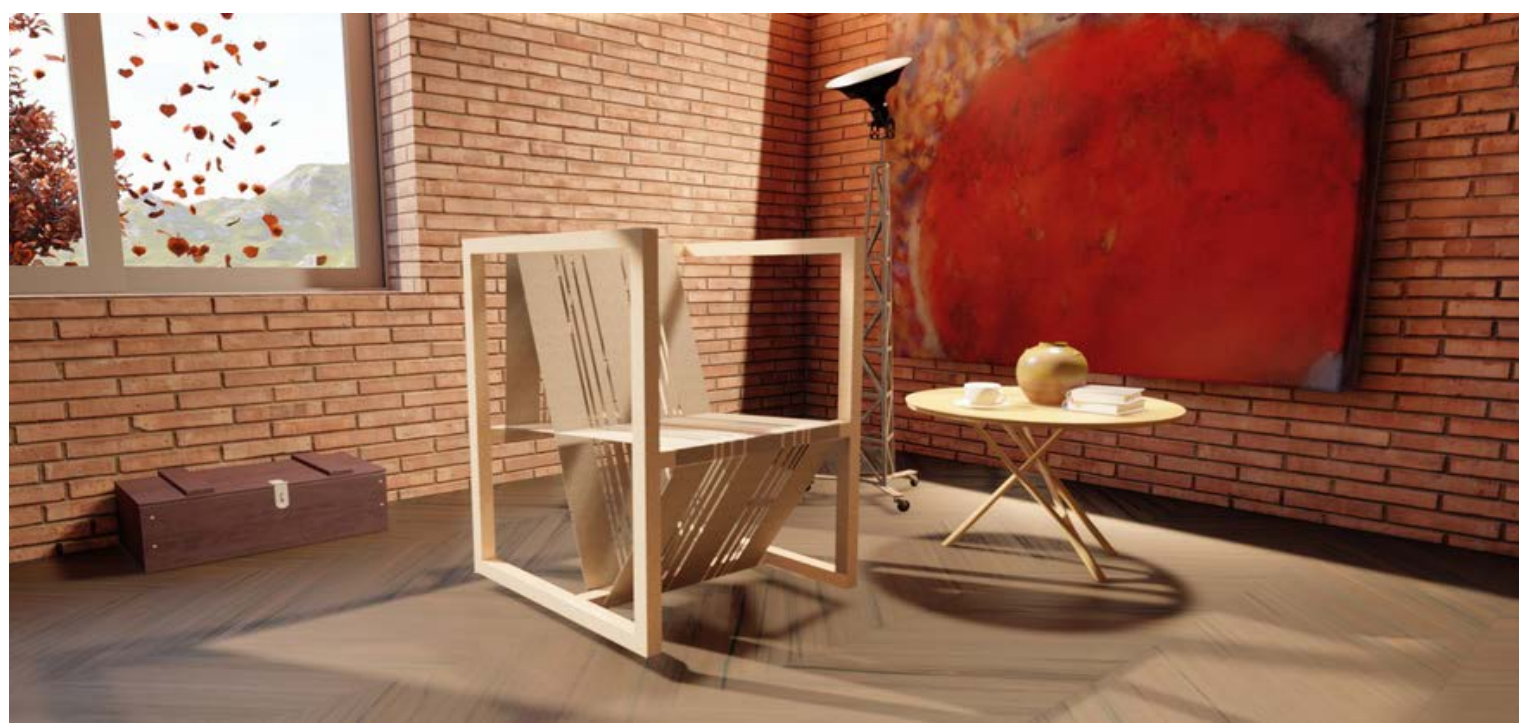

Figure 5. "Loom chair" in interior design, authors: Alexandrov Artem, Lașun Elena, Bocicov Evghenii, gr. ARH-153.

"Zig Zag chair", concept inspired by the one designed by Gerrit Rietveld in 1934, with an approach to the sustainability of plywood reuse, contemporary presentation of a striped graphic decor, with storage surfaces and a graceful shape, is the creation of the student team: Fusa Vitalii, Brăilean Adelina, Andeev Victor (gr. ARH 153) Figure 6.
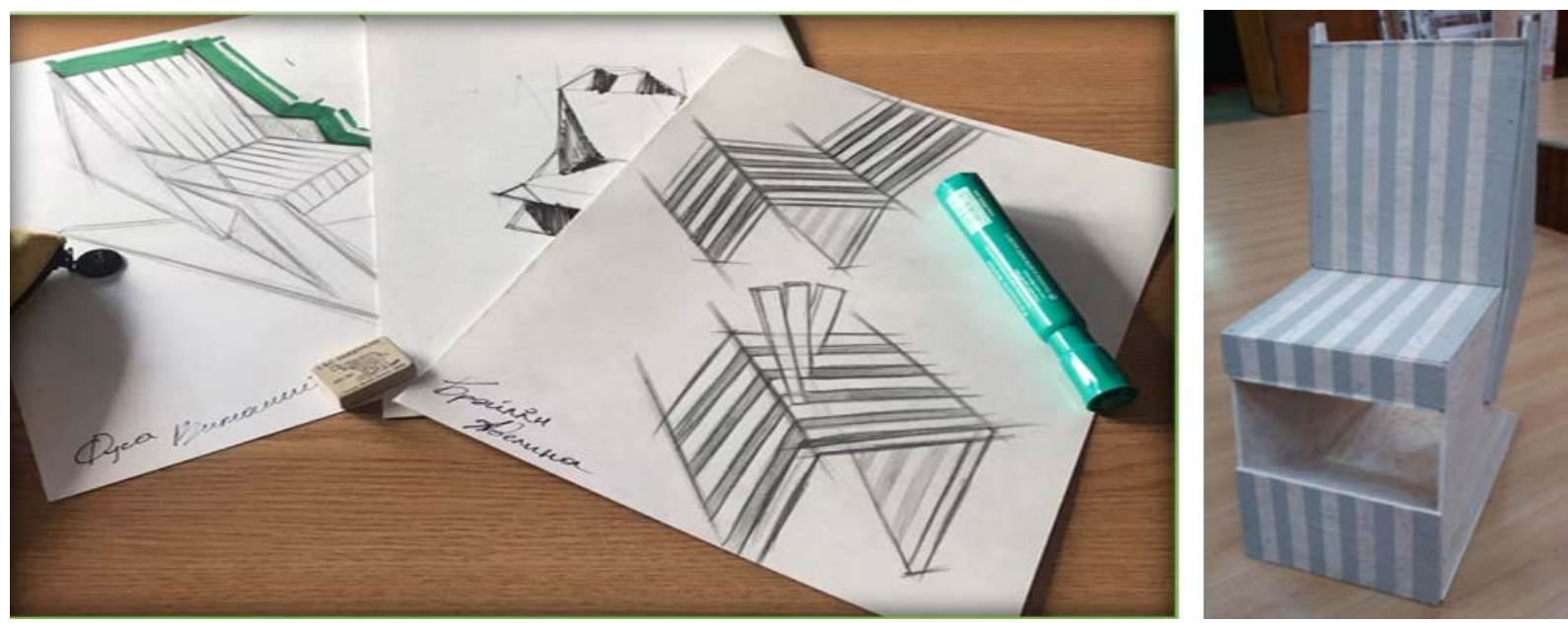

Figure 5. The project "Zig zag chair", authors: Fusa Vitalii, Brăilean Adelina, Andeev Victor, gr. ARH-153.

Thus, through the works of the Scientific-Practical Seminar: Eco-design: Sustainable furniture pieces, a message is transmitted to the academic environment but also to our society for a healthy environment, a healthy thinking, a healthy planet for the future.

Original, functional and comfortable pieces of furniture, suitable in interior design stylistics, distinguished by shape, combination of recycled and reused materials, bionic construction thinking, inspired by plants and tree stems, with surfaces highlighted by decorative lighting, materials and colors.

This project allowed students to use a variety of materials: cardboard tubes, pressed and embossed cardboard, glass, tree branches, tires, old objects, etc., which found their place in this event at the first edition Figure 6, a, b, c and Figure 7, a, b. 

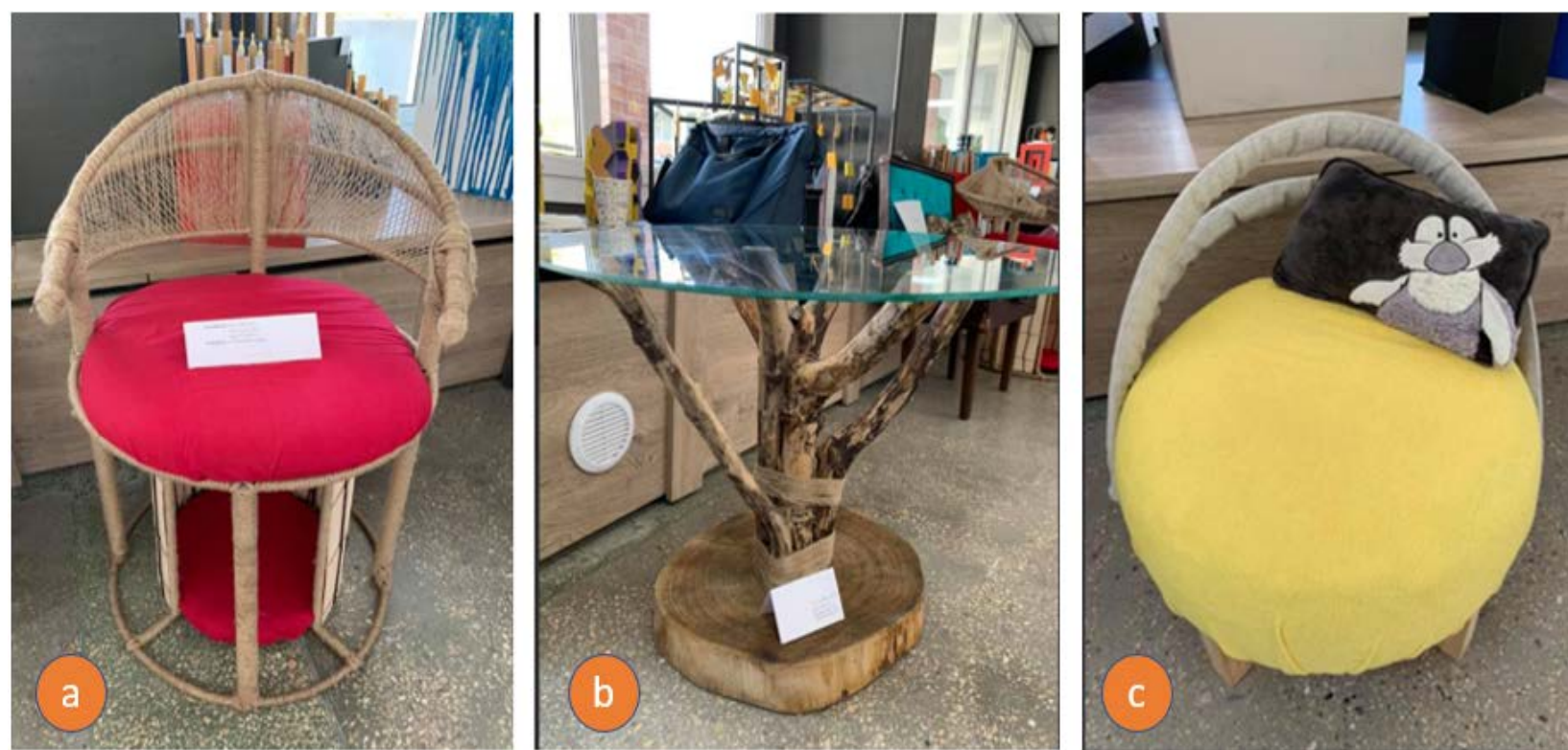

Figure 6. a) Armchair, authors: Romanenco Ana, Agachi Victoria, gr. ARH-152;

b) Modern table with rustic legs, authors: Burdeinaia Daria, Levițcaia Ecaterina,

Stolearenco Artiom, gr. ARH-153;

c) Armchair, authors: Cristalov Svetlana, Cuptor Cristina, Cuzmiciova Elena, gr. ARH-153.
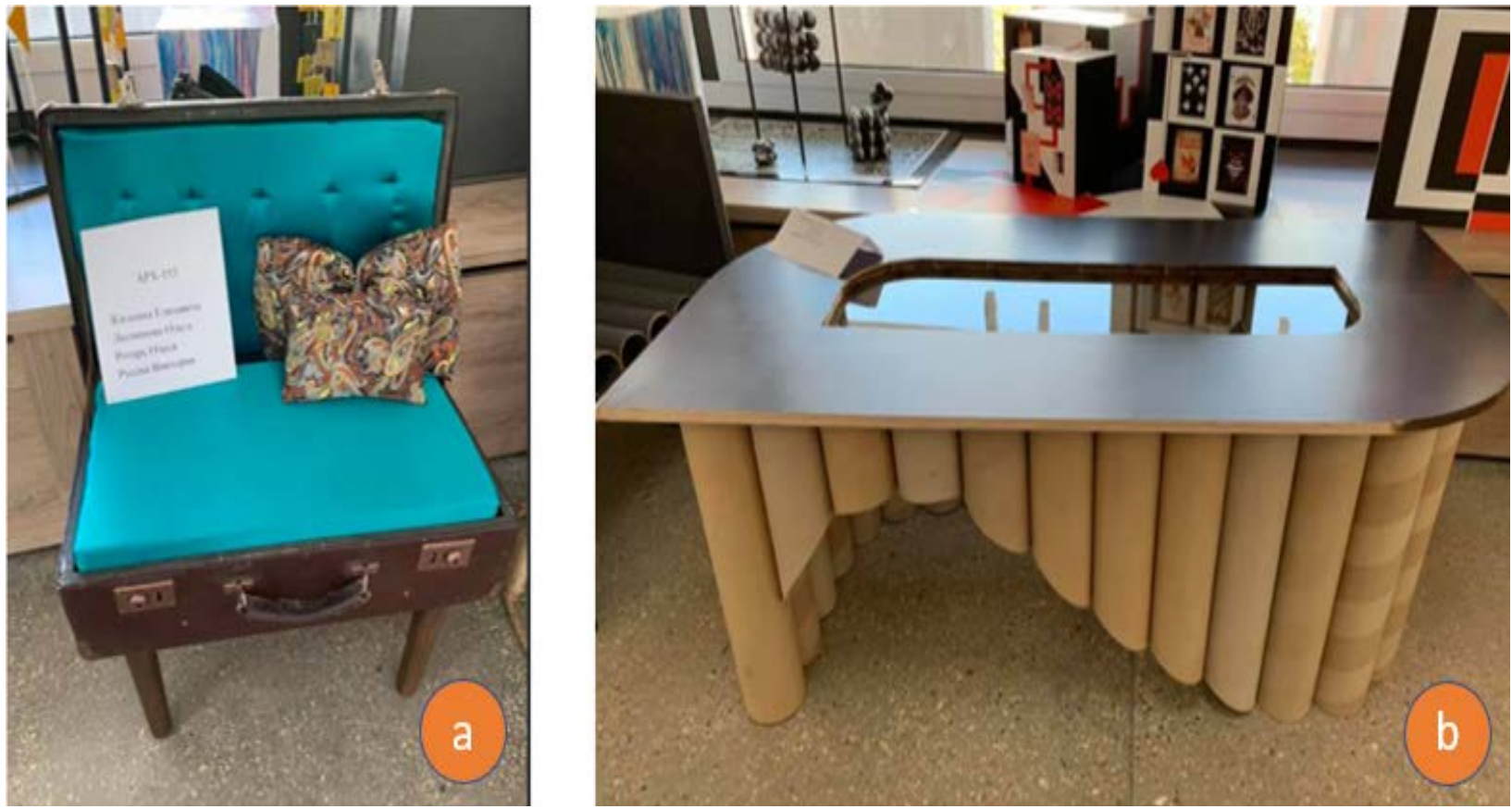

Figure 7. a) Suitcase armchair, authors: Jilchina Elizaveta, Litvinova Olga, Rotari Olesea, Ruseva Victoria, gr. ARH-153;

b) Modern table with legs made of cardboard tubes and illuminated headboard, authors: Leahu Mihaela, Cociul Victor, Sandu Victor, gr. ARH-152.

The form of the parametric architecture, of the forms conceived by nature, are rendered by the furniture works executed from pressed and embossed cardboard, from modular elements by intersection, from stylized forms of the natural elements, but also transformable furniture Figure 8, a, b, c. 

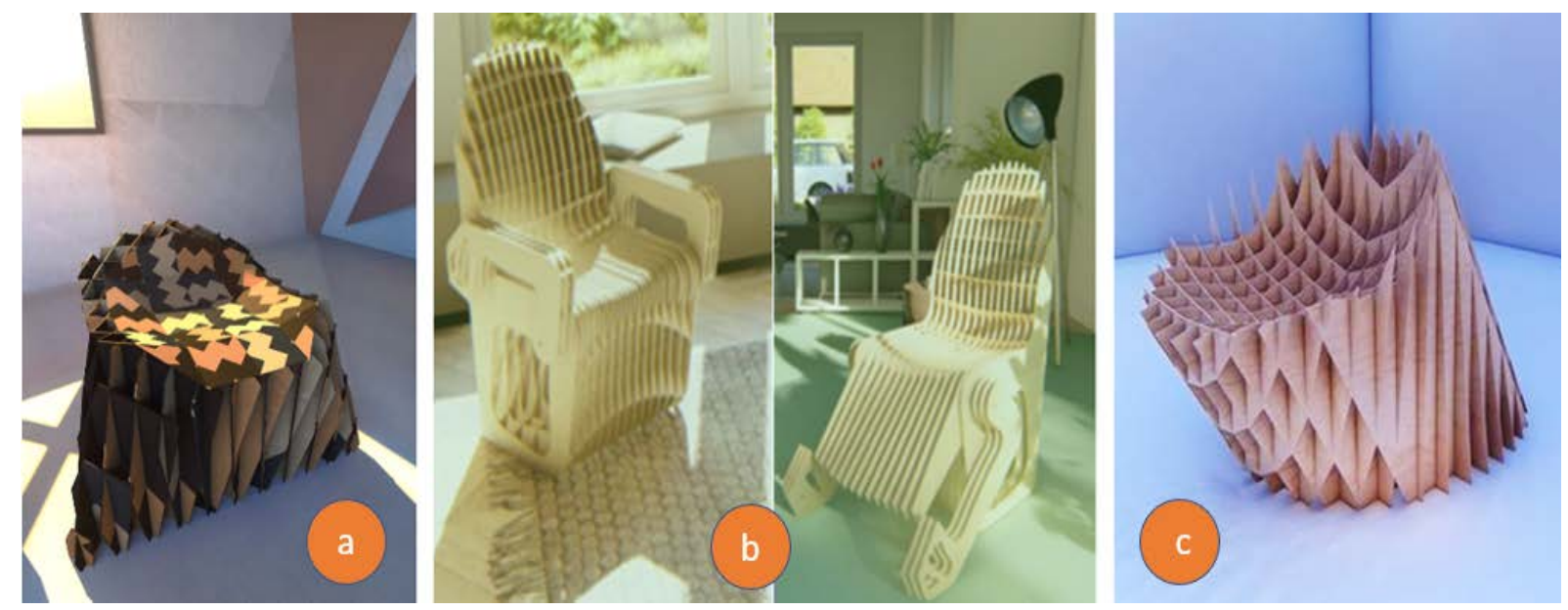

Figura 8. a) Stump armchair, authors: Fabian Florin, Fedco Octavian, Bugeacu Elena, gr. ARH-151;

b) Convertible armchair, authors: Șincari Cristina, Chiracosean David, Chebac Oleg, gr. ARH-151;

c) Armchair, authors: Calmațui Vasile, Sacal Cristina, Tomița Cristina, gr. ARH-151.

The seating furniture was in the top of the students' preferences: chairs, armchairs and stools, customized to a style and area in the home or office, relaxation spaces, etc. Figure 9 , Figure 10.
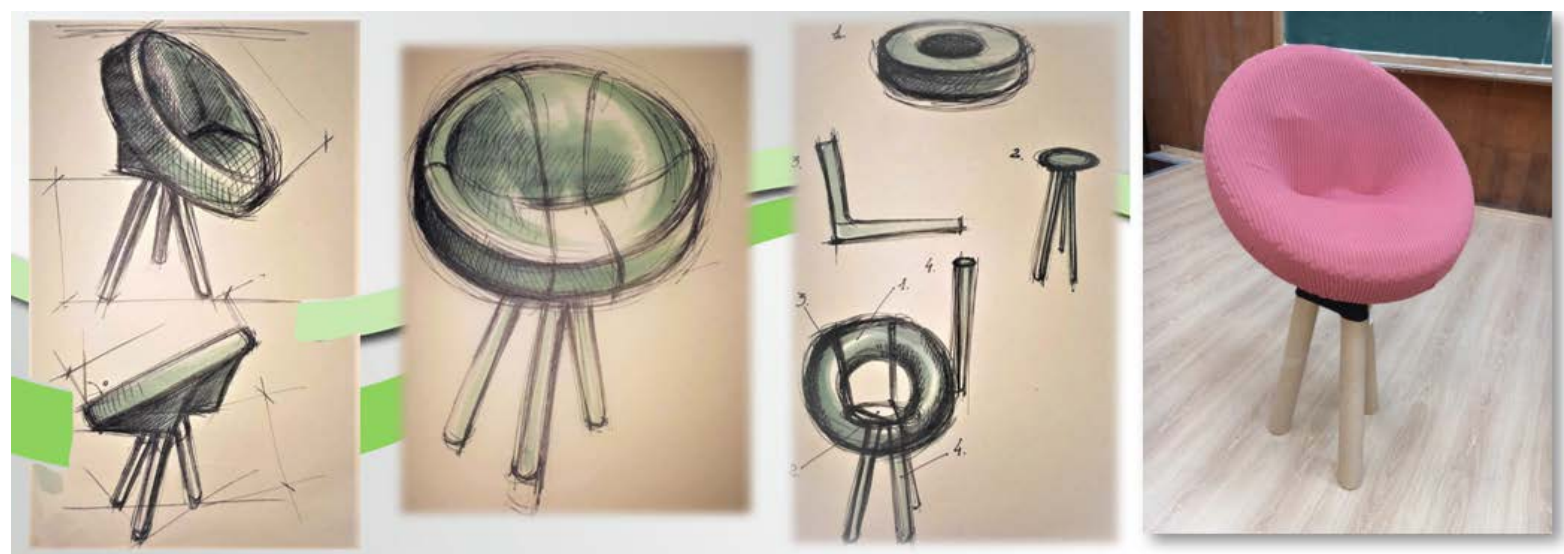

Figure 9. Armchair with rotation mechanism, authors: Gheorghița Nadejda,

Țurcan Marius, Voronețchi Diana, gr. ARH-151.
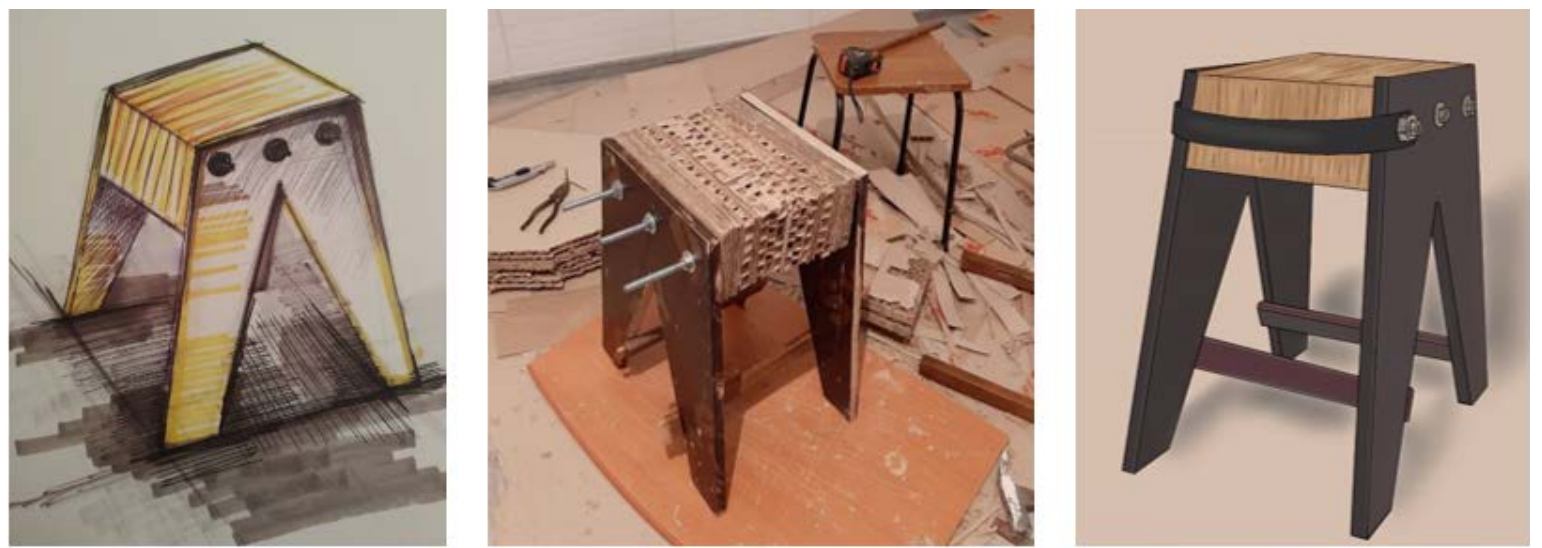

Figure 10. Stool, authors: Cojocari Elena, Raicu Dumitru, gr. ARH-151. 
The idea of transformable furniture was for the project: Transformable drawers. Construction of metal pipe reusing it for the furniture case (painted with eco paints), completed with storage boxes with over 70 proposals for organization. The authors of the project Dobinda Dana, Mînăscurtă Ana, Nistor Căti-Cătălina were inspired by geometric shapes: square and triangle, which inspire balance and urge us to be as rational, more persevering, more organized. Such furniture is welcome for interior spaces: living room, bedroom, office, and the decoration on the surface makes a perfect interference of square and triangle shapes Figure 11, Figure 12.
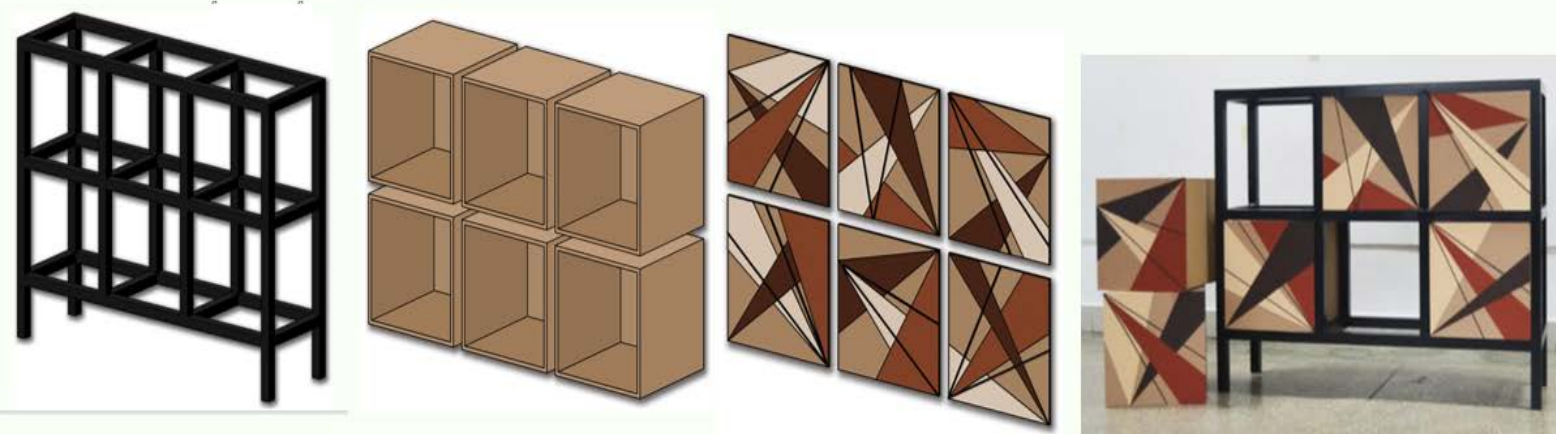

Figure 11. Transformable drawers, work steps authors: Dobinda Dana, Mînăscurtă Ana, Nistor Căti-Cătălina, gr. ARH-152.

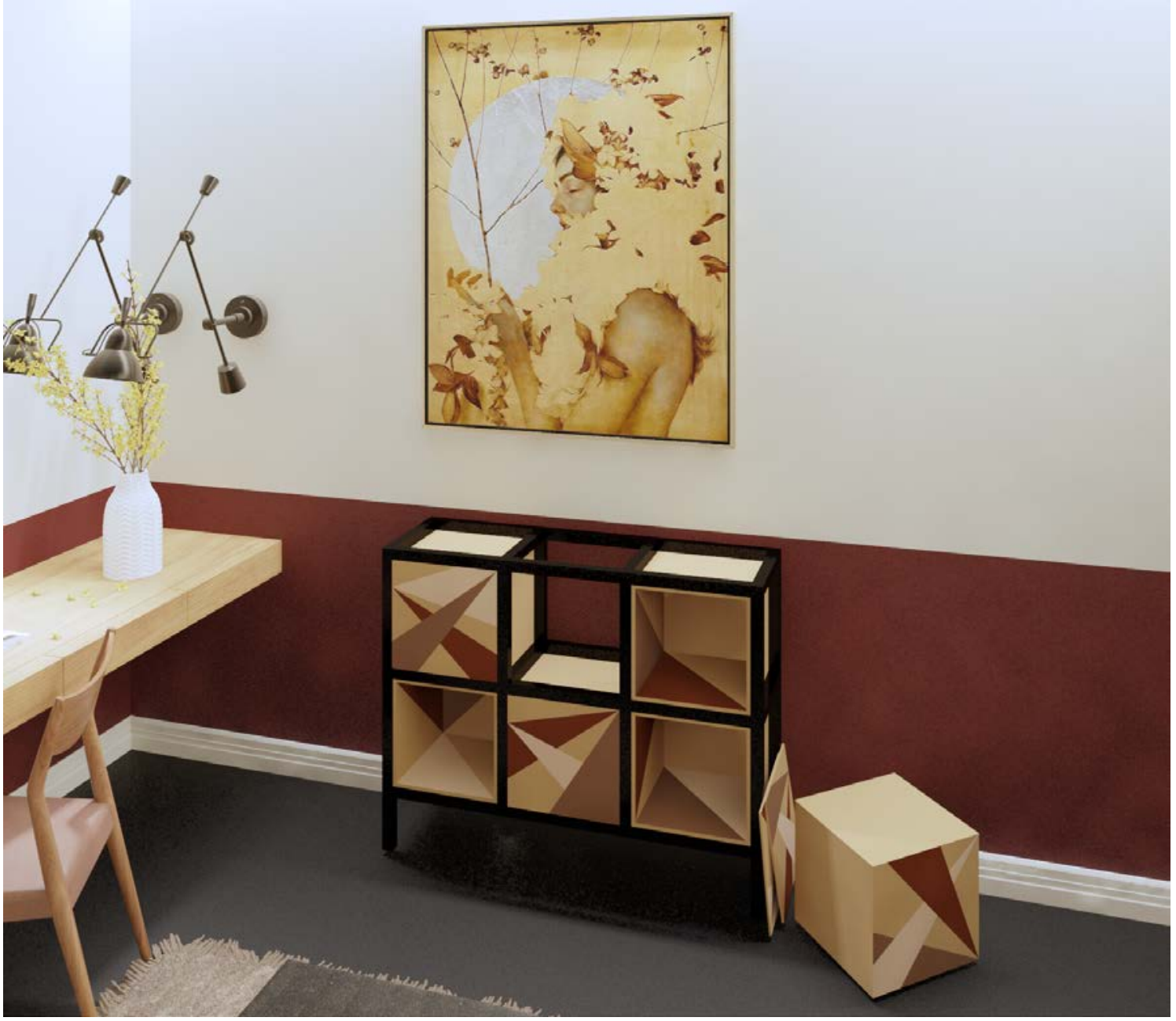

Figure 12. Transformable drawers, in interior design authors: Dobinda Dana, Mînăscurtă Ana, Nistor Căti-Cătălina, gr. ARH-152. 

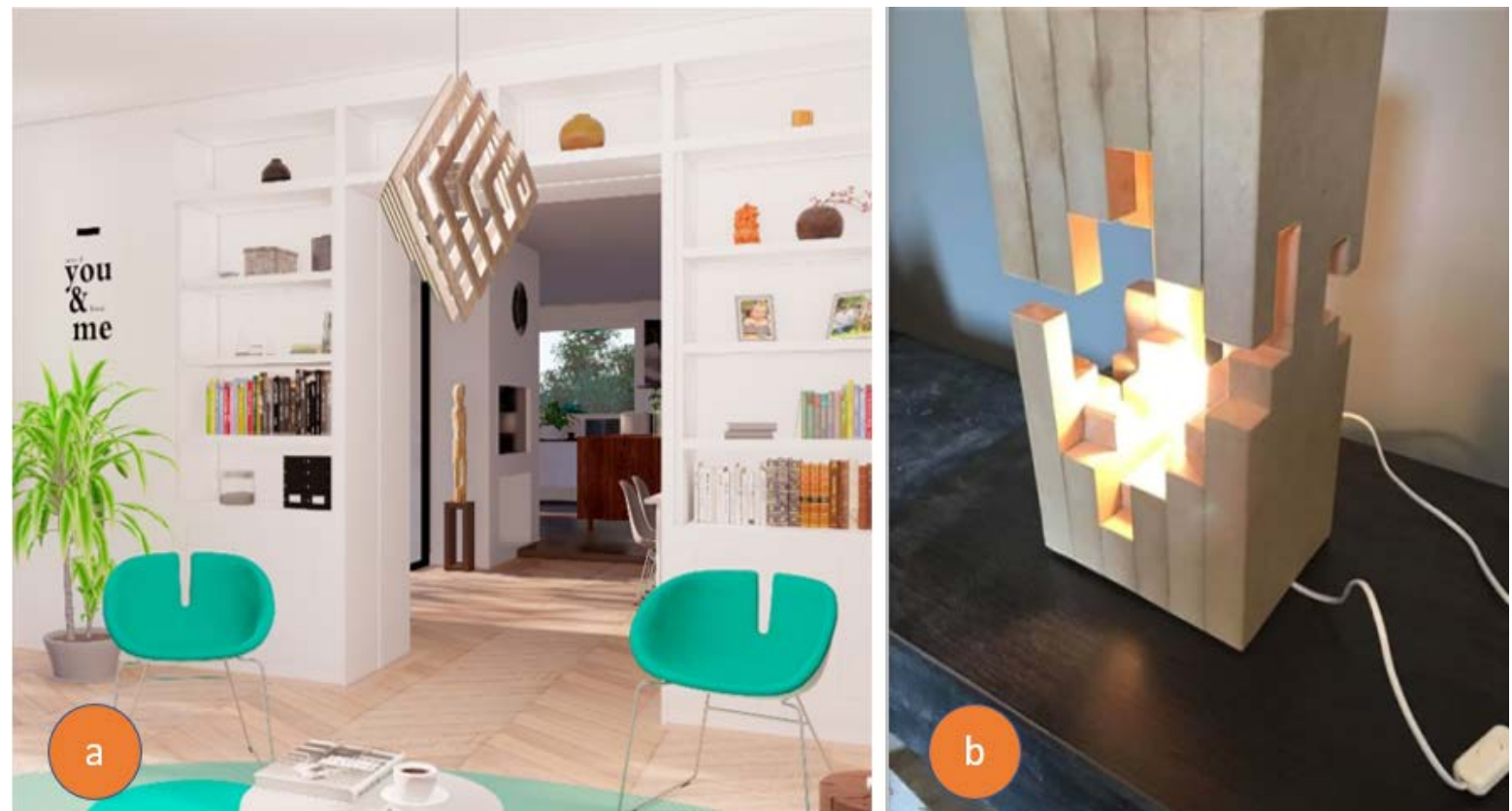

Figure 13. a) Suspension, interior design, author: Bala Radă, gr. ARH-142

b) Table lamp, author: Țaga Carolina, gr. ARH-152.

Another ecological design project was for last year's students (gr. ARH-141, 142), who presented lighting fixtures made from recycled materials (wood, plywood, metal, colored glass), biodegradable, functional, respecting the interior design style: contemporary, bionic [9 - 12].

An original work is the decorative panel - "Gates of Chisinau", inspired by the representative gates of the capital of the Republic of Moldova, representative panel for the project - "5 Star Hotel". Suspensions, table lamps are integrated in addition to artificial lighting in interior design Figure 13, a, b and Figure 14.

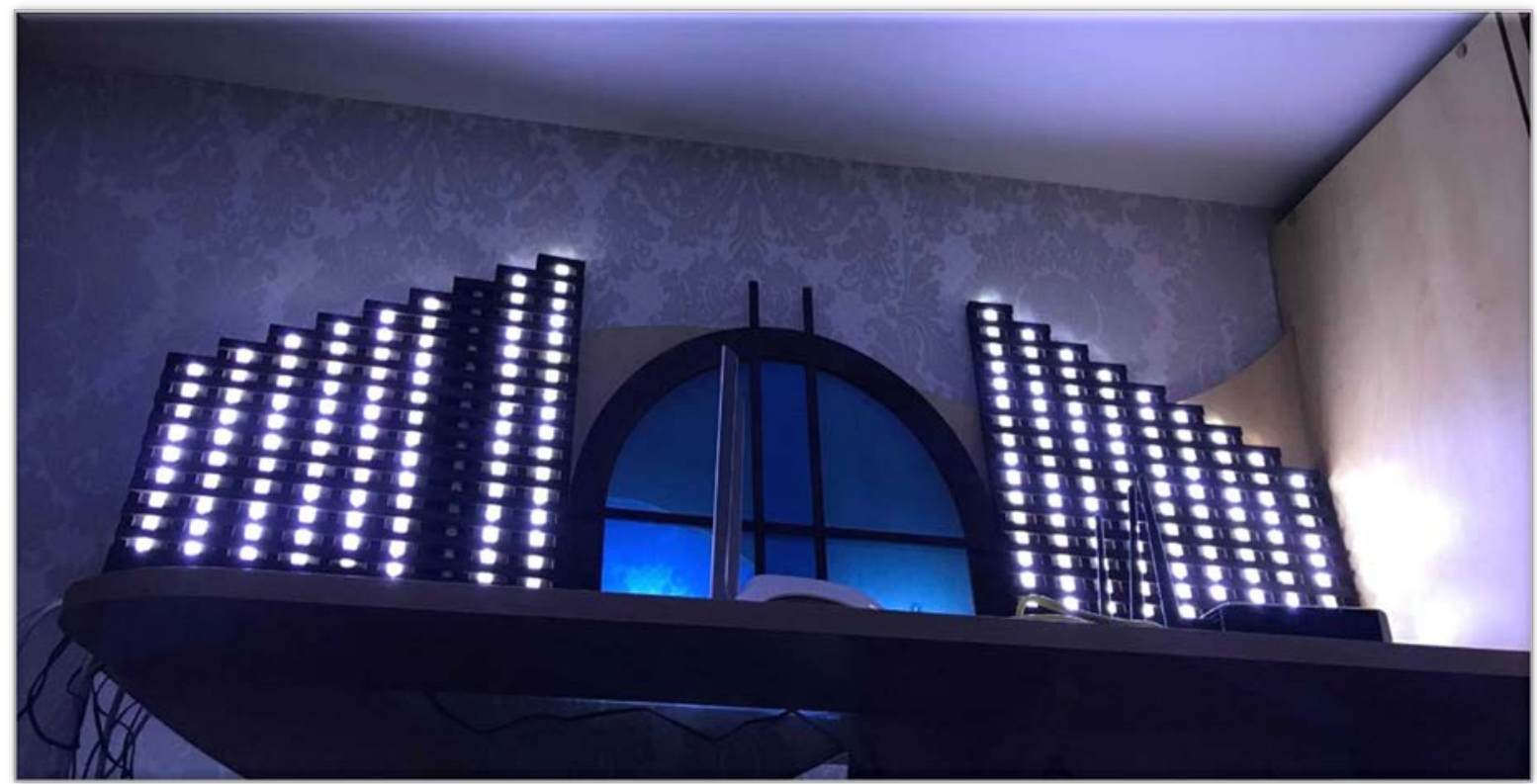

Figure 14. Decorative panel - "Gates of Chisinau", author: Cazarinov Olga, gr. ARH-142. 


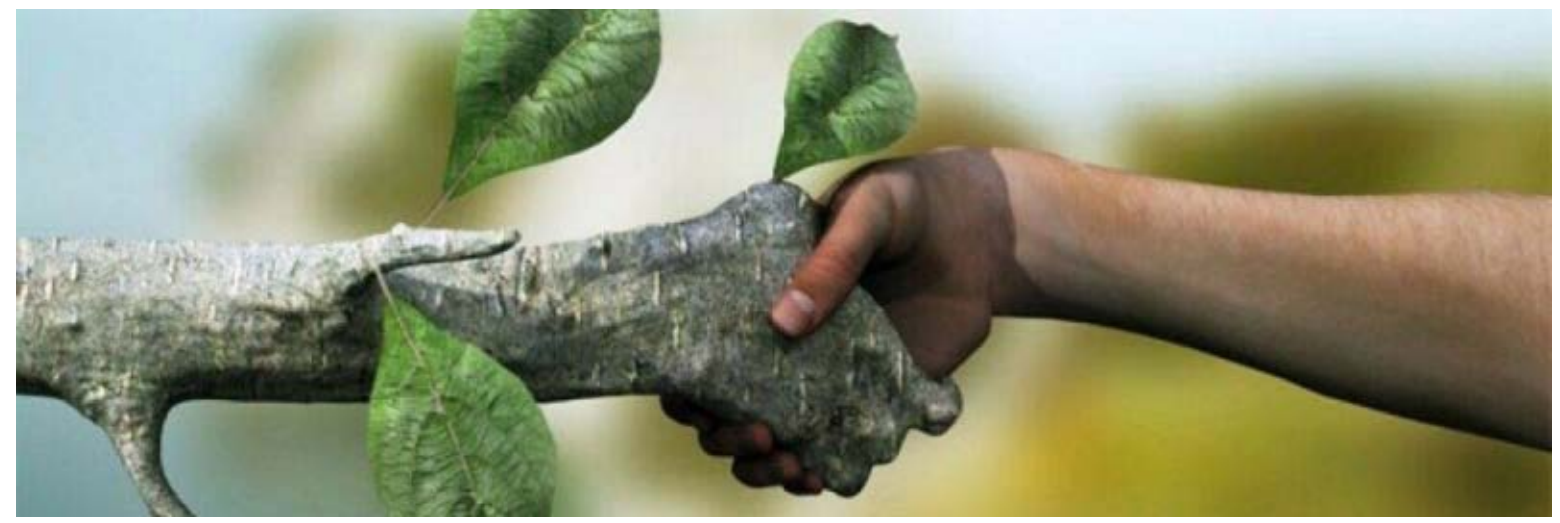

\section{Conclusions}

Ecological thinking brings new challenges, but at the same time offers completely new opportunities. Today, through the training process of the future architects and designers of this event we transmit the message of the ecological problem, by applying sustainable thinking and design now and then in professional activity, starting from the green stereotype to a practical application through technology.

In the end, we can say that we should learn to value nature, to reduce, reuse, and last but not least to recycle everything to preserve and maintain all the richness and beauty of the environment: " A cleaner and healthier environment starts with you!"

\section{Bibliography}

1. Kant I. Observaţii asupra sentimentului de frumos şi sublim, traducere de Rodica Croitoru, Editura All, Bucureşti, 2008, ISBN 5-322-00020-8, p. 120

2. Aloone M., Bey N. Îmbunătăţirea mediului prin dezvoltarea de produse. Ghid, EPA daneză, Copenhaga Danemarca, 2009, ISBN 978-87-7052-950-1, p. 46

3. Papanek V. Design pentru lumea reală: ecologie umană și schimbare socială (Design for the Real World: Human Ecological and Social Change), Chicago: Ediția Academiei, ISBN, 1972, 0-394-47036-2, p. 185

4. Papanek V. Imperativul verde: design natural pentru lumea reală, New York, Thames și Hudson, 1995, ISBN 0-500-27846-6, p. 195

5. Benyus J. Biomimicry: Innovation Inspired by Nature. New York, USA: William Morrow \& Company, 1997, ISBN 978-0-688-16099-9

6. Lindahl M. Utilizarea de către designer a metodelor ecologice și durabile. Progresele primului atelier internațional privind "Consumul durabil", 2003. Tokyo, Japonia, Societatea Tehnologiei Non-Tradiționale (SNTT) și Centrul de Cercetare pentru Evaluarea Ciclului de Viață (AIST)

7. Shedroff N. Designul este problema: viitorul design-ului trebuie să fie durabil. Design Journal: volumul 13, numărul 1, martie 2010

8. Gross M. Ignoranță și surpriză: știință, societate și design ecologic. Publicat de MIT Press, 2010, ISBN 0-262-01348-7, p. 127

9. What is sustainability - https://www.twi-global.com/locations/romania/ce-facem/intrebari-frecvente-faq/ceeste-sustenabilitatea (visited 09.05.2021)

10. Sustainability - Wikipedia, the free encyclopedia, https://ro.wikipedia.org/wiki/Sustenabilitate (visited 25.06.2021)

11. Towards global sustainability https://www.eea.europa.eu/ro/articles/catre-o-sustenabilitate-globala (visited 05.07.2021)

12. Transitions to sustainability https://www.eea.europa.eu/ro/themes/tranzitii-catre-sustenabilitate/intro (visited 05.07.2021) 